\title{
Lasers for Removing Obturation Materials and Medicaments from the Root Canal: A Review
}

\author{
Mohamad Abduljalil' (1), Burcu Gunal Abduljalil2 (1) \\ 'Department of Endodontics, Faculty of Dentistry, Near East University, MersinI0, Turkey \\ ${ }^{2}$ Department of Prosthodontics, Faculty of Dentistry, Near East University, MersinI0, Turkey
}

ORCID iD of the author: M.A. 0000-0002-2244-9285; B.G.A. 0000-000I-5098-1765.

Cite this article as: Abduljalil M, Gunal Abduljalil B. Lasers for Removing Obturation Materials and Medicaments from the Root Canal: A Review. Cyprus J Med Sci 2020; 5(3): 254-9.

\begin{abstract}
The complete removal of obturation materials from root canals is an important factor for successful endodontic retreatment. Many devices and techniques have been introduced for improving the removal of root fillings. A laser is one of the most effective devices. The application of different types of laser devices such as erbium: yttrium aluminium garnet (Er:YAG), erbium chromium: yttrium scandium gallium garnet (Er,Cr:YSGG), neodymium-doped: yttrium aluminum garnet (Nd:YAG), and neodymium-doped: yttrium aluminum perovskite (Nd:YAP) can effectively remove obturation materials and canal medicaments from the root canal system. However, regardless of the type of laser, these devices have some disadvantages when using them in the root canals. Thermal effects such as carbonization areas and partial dissolution in the gutta-percha and dentine have been observed after laser applications. Unfortunately, none of the retreatment protocols or laser types was able to remove the remnants of filling materials completely from the root canal system. This review was designed to evaluate the effectiveness of different laser devices in removing obturation materials and medicaments from the root canal system.
\end{abstract}

Keywords: Filling materials, laser, removal, retreatment, root canal

\section{INTRODUCTION}

The main purpose of root canal retreatment is to remove the obturation materials completely from the root canal and to reach the apical foramen. Because the residual obturation materials and smear layer are considered to harbor microorganisms, the success of root canal retreatment depends on the complete removal of the root canal obturation materials and smear layer (I). Many techniques and devices can be used to remove the obturation materials, including hand files, rotary systems, reciprocal systems, and solvents. However, a significant amount of residual obturation materials has been observed on the canal walls after using these techniques (2-4). Therefore, supplementary procedures should be applied after using hand or rotary files to improve the cleaning and complete removal of the obturation materials from root canals. Several devices have been introduced for this aim, including sonic, ultrasonic, and laser devices.

The first use of laser in endodontic treatment was in 1971 by Weichman and Johnson (5). In the following years, many studies have been conducted to evaluate the application of laser in the root canal $(6,7)$. In addition to the use of laser devices in disinfection and preparation of the root canals, several studies have been conducted to evaluate the efficacy of different types of lasers to remove the gutta-percha and sealers from the root canal during the endodontic retreatment $(8,9)$. In the literature, the laser devices used in removing the obturation materials included erbium: yttrium aluminium garnet (Er:YAG), erbium chromium: yttrium scandium gallium garnet (Er,Cr:YSGG), neodymium-doped: yttrium aluminum garnet (Nd:YAG), and neodymium-doped: yttrium aluminum perovskite ( $N d$ :YAP) lasers. These laser devices, which have different wavelengths, were evaluated in different output powers to remove not only the obturation materials but also the root canal medicaments.

During the root canal retreatment, several studies have been conducted to evaluate the efficacy of different types of laser devices in endodontic retreatment. Hence, this review aimed to identify studies that investigated the effectiveness of different laser devices on removing the obturation materials and medicaments from the root canal system. Table I summarizes these studies that evaluated the laser devices. 


\section{Er:YAG Laser}

The Er:YAG laser was introduced in 1975, and it was the first laser approved by the Food and Drug Administration for use in hard tissues in 1977. This laser beam has a wavelength of $2940 \mathrm{~nm}$ and can be used to remove both hard and soft tissues. The Er:YAG laser's high affinity to water and hydroxyapatite results in a cleaner root canal surface (I0). Photon-induced photoacoustic streaming (PIPS) is one of the activation methods powered by the Er:YAG laser. This method uses a radial and stripped-shape design tip to transfer laser energy into the irrigant to enhance the removal of filling materials during a retreatment procedure (II).

Several studies in the literature have evaluated the use of the Er:YAG laser in removing the materials from the root canal system. Previous studies estimated the Er:YAG laser on removing the obturation materials from the root canal at a wavelength of $2940 \mathrm{~nm}$ with different output powers. The results were that the differences between several output powers were not significant in removing the filling materials $(12,13)$. At 3 energy levels $(30,40$, and $50 \mathrm{~mJ})$ of the Er:YAG laser (Dentlite; Hoya Photonics, Tokyo, Japan), the time required to remove the filling materials was significantly shorter when using the highest output power (I2). On the other hand, Gorduysus et al. (13) concluded that the difference between the removal time at 40 and $50 \mathrm{~mJ}$ powers was not significant, but that carbonization areas were observed when using these output powers. In another previous study, the Er:YAG laser (Versawave; HOYA ConBio, Fremont, CA) at 2940 $\mathrm{nm}$ and $1.5 \mathrm{~W}$ output power was compared with irrigation solutions in removing calcium hydroxide from the root canal system. The Er:YAG laser was superior to the irrigation solutions in removing calcium hydroxide, but the difference was not statistically significant (14).

The PIPS method was used in previous studies to remove the remnants of filling materials after using rotary retreatment files. PIPS (Fidelis AT; Fotona, Ljubljana, Slovenia) using the parameters of $2940 \mathrm{~nm}, \mathrm{I} \mathrm{W}, 20 \mathrm{~Hz}$, and $50 \mathrm{~mJ}$ was evaluated in oval-shaped root canals and showed significantly better performance in removing the filling remnants than sonic and ultrasonic devices (15). According to the results of Suk et al. (16), there was a significant reduction in the residual fillings when using PIPS (LightWalker; Fotona, Ljubljana, Slovenia) at $20 \mathrm{~mJ}$, regardless of the canal sealer type. However, Dönmez Özkan et al. (17) concluded that using the PIPS (Fotona) technique after different rotary retreatment systems did not show a significant additional effect regarding the removal of filling material compared with conventional needle irrigation. In addition, many studies

\section{Main Points:}

- The success of root canal retreatment depends on the complete removal of the root canal obturation materials and smear layer.

- The application of laser devices can effectively remove the obturation materials and canal medicaments from the root canal system.

- The time of laser irradiation and energy power used should be considered when applying the laser in the root canal to avoid the thermal effects. have evaluated the effect of using the PIPS method on removing different types of canal medicaments compared with other devices. All results showed that PIPS was significantly superior in removing the canal medicaments, regardless of the parameters used (|8-2|).

\section{Er,Cr:YSGG Laser}

One of the erbium laser group, the Er,Cr:YSGG laser has a 2780 $\mathrm{nm}$ wavelength. The Er,Cr:YSGG laser requires higher energy than the Er:YAG laser for dental hard tissue ablation when used at the same parameters (22).

Some studies were found in the literature reporting on the use of the Er,Cr:YSGG laser in removing the canal medicaments and obturation materials. Using the Er,Cr:YSGG laser (Waterlase; Biolase Technology, Irvine, CA) at $25 \mathrm{~mJ}$ and $20 \mathrm{~Hz}$ left significantly less medicaments in the canal when compared with the irrigation needle $(23,24)$. Abduljalil and Kalender $(25)$ evaluated the Er,Cr:YSGG laser (Waterlase MD; Biolase) for removing the filling materials at 2 different output powers after using rotary files. Regardless of the obturation technique, they reported that using the Er,Cr:YSGG laser at the parameters of $2780 \mathrm{~nm}, 20 \mathrm{~Hz}$ and 3.0 W was significantly more effective in removing the filling remnants than at the $1.5 \mathrm{~W}$ output power of this laser. However, using the Er,Cr:YSGG laser at 3.0 W power caused carbonization on the canal walls in some specimens.

\section{Nd:YAG Laser}

A fine flexible glass fiber made of quartz has been developed for the Nd:YAG laser to transmit the laser beam more effectively and to permit its concentration in a specific area. This has increased the potential usefulness of the $\mathrm{Nd}$ :YAG laser in root canal treatment and it is expected that the Nd:YAG laser will be increasingly used in the dental clinic, especially in the field of endodontics. This laser device is used at a $1064 \mathrm{~nm}$ wavelength (26).

The Nd:YAG laser has been investigated for removing the filling materials in many studies. According to the evaluation of Anjo et al. (26), using the Nd:YAG laser (STATLase EPY; ARA400, S.L.T. JAPAN, Tokyo, Japan) at $1064 \mathrm{~nm}$ and $900 \mathrm{~mJ}$ per pulse was superior to Gates-Glidden drills in removing 2 types of filling materials. Also, the time required for the removal of obturation materials was significantly shorter in the Nd:YAG laser groups. Yu et al. (27) reported that using the Nd:YAG laser (d-Lase 300; American Dental Laser, Birmingham, MI) at I, 2 and, $3 \mathrm{~W}$ powers, respectively, and at $1064 \mathrm{~nm}$ removed the filling materials completely in $70 \%$ of the tested samples, but the temperature was increased up to $27^{\circ} \mathrm{C}$. Viducic et al. (28) evaluated this laser (Twinlight Dental Laser; Fotona, Slovenia) with or without solvents and found that the area of remaining gutta-percha was smaller when using the laser at $20 \mathrm{~Hz}$ and $1.5 \mathrm{~W}$ without solvents, but that the difference was not statistically significant. In addition, the shortest time to achieve the working length of the canal was found in the group without solvents. In a study by Majori et al. (29), the effect of using the Nd:YAG laser (Pulse Master 600 IQ; American Dental Technologies, Corpus Christi, TX) was investigated in root canal retreatment. They reported that the higher output power $(5.6 \mathrm{~W})$ was better in the removal of obturation materials than the other output powers (I.5 and 2 W). When comparing the Nd:YAG laser with the K3 rotary sys- 
TABLE I. Summary of studies evaluating lasers on removing the obturation materials and medicaments from the root canal.

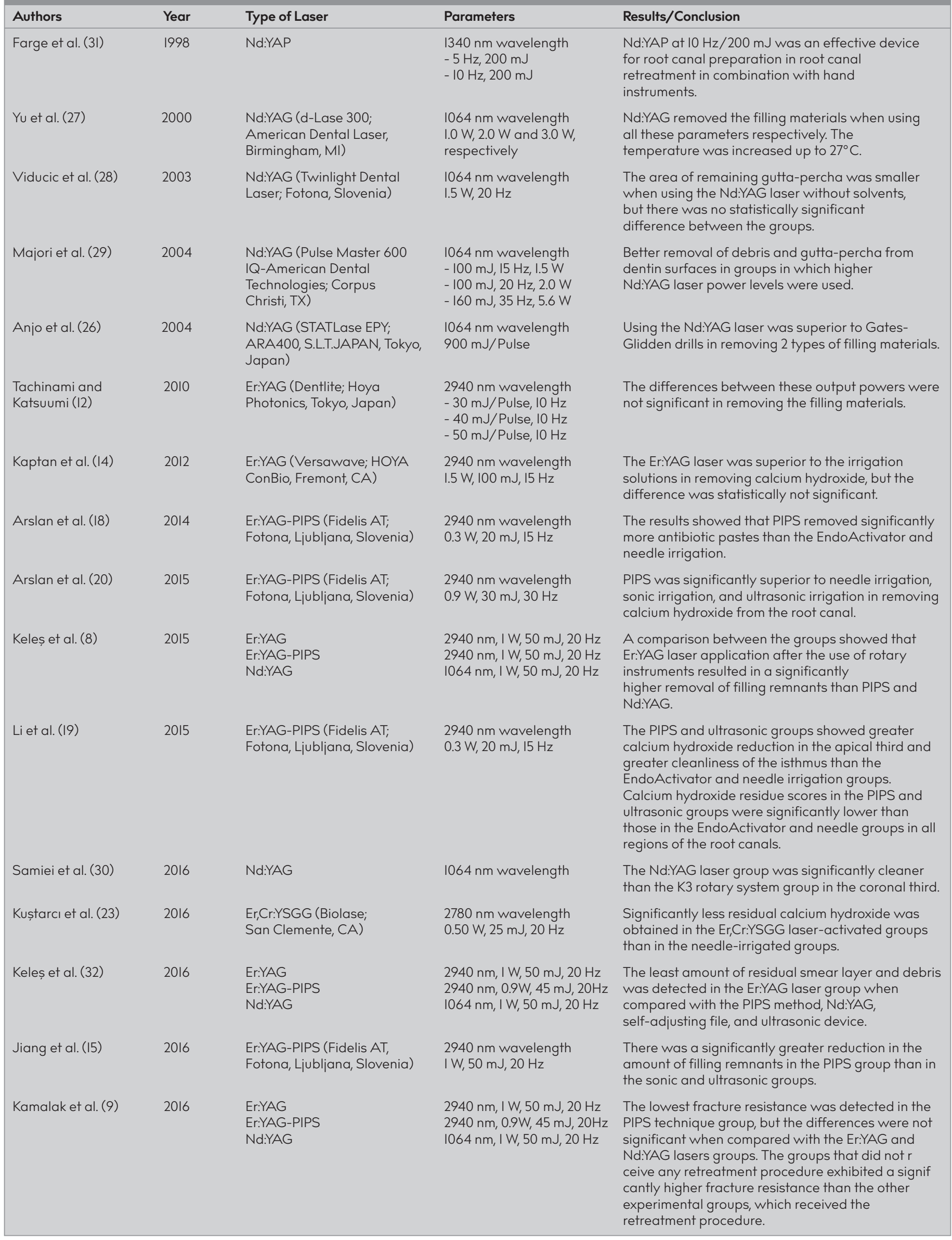


TABLE I. Summary of studies evaluating lasers on removing the obturation materials and medicaments from the root canal. (Continued)

\begin{tabular}{|c|c|c|c|c|}
\hline Authors & Year & Type of Laser & Parameters & Results/Conclusion \\
\hline Eymirli et al. (24) & 2017 & $\begin{array}{l}\text { Er,Cr:YSGG (Waterlase; } \\
\text { Biolase Technology, } \\
\text { Irvine, CA) }\end{array}$ & $\begin{array}{l}2780 \mathrm{~nm} \text { wavelength } \\
25 \mathrm{~mJ}, 20 \mathrm{~Hz}\end{array}$ & $\begin{array}{l}\text { For both EDTA and phytic acid, Er,Cr:YSGG } \\
\text { laser-activated irrigation was more efficient than } \\
\text { needle irrigation in removing both CH and TAP, but } \\
\text { none of the tested techniques completely removed } \\
\text { calcium hydroxide. Irrespective of the tested } \\
\text { irrigation solutions and techniques, significantly less } \\
\text { TAP remained in canals, with TAP being completely } \\
\text { removed by laser-activated irrigation. }\end{array}$ \\
\hline Suk et al. (16) & 2017 & $\begin{array}{l}\text { Er:YAG-PIPS (LightWalker, } \\
\text { Fotona, Ljubljana, Slovenia) }\end{array}$ & $\begin{array}{l}2940 \mathrm{~nm} \text { wavelength } \\
20 \mathrm{~mJ}, 2.06 \mathrm{~J} / \mathrm{cm} 2,15 \mathrm{~Hz}\end{array}$ & $\begin{array}{l}\text { Regardless of the canal sealer type, there was } \\
\text { significant reduction of the filling remnants after } \\
\text { canal irradiation by PIPS in all groups. }\end{array}$ \\
\hline Laky et al. (2l) & 2018 & $\begin{array}{l}\text { Er:YAG-PIPS (Lightwalker, } \\
\text { Fotona, Ljubljana, Slovenia) }\end{array}$ & $\begin{array}{l}2940 \mathrm{~nm} \text { wavelength } \\
-0.15 \mathrm{~W}, 10 \mathrm{~mJ}, 15 \mathrm{~Hz} \\
-1.0 \mathrm{~W}, 25 \mathrm{~mJ}, 40 \mathrm{~Hz}\end{array}$ & $\begin{array}{l}\text { No significant differences were found for calcium } \\
\text { hydroxide removal between the } 2 \text { PIPS technique } \\
\text { groups. Sonic-assisted removal and needle } \\
\text { irrigation resulted in significantly less calcium } \\
\text { hydroxide removal than both laser groups. }\end{array}$ \\
\hline $\begin{array}{l}\text { Dönmez Özkan } \\
\text { et al. (17) }\end{array}$ & 2019 & Er:YAG-PIPS (Fotona) & $\begin{array}{l}2940 \mathrm{~nm} \text { Wavelength } \\
0.3 \mathrm{~W}, 20 \mathrm{~mJ}, 15 \mathrm{~Hz}\end{array}$ & $\begin{array}{l}\text { Using the PIPS method after different rotary } \\
\text { retreatment systems did not show a significant } \\
\text { additional effect regarding the removal of filling } \\
\text { material compared with conventional needle } \\
\text { irrigation. }\end{array}$ \\
\hline $\begin{array}{l}\text { Abdulialil and } \\
\text { Kalender (25) }\end{array}$ & 2019 & $\begin{array}{l}\text { Er,Cr:YSGG (Waterlase } \\
\text { MD; Biolase, Irvine, CA) }\end{array}$ & $\begin{array}{l}2780 \mathrm{~nm} \text { Wavelength } \\
-1.5 \mathrm{~W}, 75 \mathrm{~mJ}, 20 \mathrm{~Hz} \\
-3.0 \mathrm{~W}, 150 \mathrm{~mJ}, 20 \mathrm{~Hz}\end{array}$ & $\begin{array}{l}\text { Regardless of the obturation technique, using the } \\
\text { Er,Cr:YSGG laser was significantly more effective in } \\
\text { removing the filling remnants than I.5 W output } \\
\text { power of this laser. }\end{array}$ \\
\hline
\end{tabular}

tem for root canal retreatment, the laser group was significantly cleaner than the K3 rotary system group in the coronal third. Additionally, the mean time necessary for the debridement of root canals in the laser group was significantly shorter than that in the $\mathrm{K} 3$ group (30).

\section{Nd:YAP Laser}

Limited information was found in the literature regarding the use of the Nd:YAP laser in root canals. Farge et al. (3I) evaluated the Nd:YAP laser in endodontic retreatment. This laser, which was used in that study at with the parameters of $1340 \mathrm{~nm}$ wavelength, $10 \mathrm{~Hz}$, and $200 \mathrm{~mJ}$, was an effective device for root canal preparation in root canal retreatment when used with hand instruments.

\section{Combinations of Lasers}

Several article in the literature have compared different types of laser devices. One of these studies that used microcomputed tomography has concluded that a comparison between laser groups showed that Er:YAG laser (Fidelis AT; Fotona, Ljubliana, Slovenia) irradiation after retreatment with rotary instruments demonstrated a significantly greater removal of filling remnants than Er:YAG laser-based PIPS and Nd:YAG laser (Fotona). An output power of I W was used for these laser devices and the wavelengths were set according to the manufacturer instructions (8). Furthermore, a study by Keleș et al. (32) reported that the least amount of residual smear layer and debris was detected with the Er:YAG laser (Fidelis AT, Fotona, Ljubljana, Slovenia) group when compared with the PIPS technique, the Nd:YAG laser (Fidelis AT; Fotona), a self-adjusting file, and an ultrasonic device. Kamalak et al. (9) reported that the fracture resistance of the tooth was evaluated after performing retreatment procedures with different lasers and other devices. The groups that did not receive any retreatment procedure exhibited a significantly higher fracture resistance than the other experimental groups that received the retreatment procedure. The lowest fracture resistance was detected when the PIPS method was used (2940 nm; Fotona), but the differences were not significant when compared with the Er:YAG (2940nm, Fidelis AT; Fotona, Ljubljana, Slovenia) and Nd:YAG (I064 nm; Fotona) laser groups.

According to this review, different types of laser devices have been evaluated for the removal of filling materials and medicaments from the root canal system in many studies. These lasers were used in several ways at different output powers and in combination with other tools and materials such as irrigation solutions or solvents.

In general, the laser device is an effective tool to clean filling materials from the root canal system. However, regardless of the retreatment procedure or laser type, the removal of the filling materials was reportedly more effective in the coronal and middle third than the apical third in several previous studies $(25,32)$. This could be because of the increased number of lateral and accessory canals in the apical third. In addition, moving the fiber tip of the laser in circular movements in the coronal and middle thirds and in parallel movements without touching the canal wall in the apical third could be another reason for this finding.

Regardless of the laser type used, thermal effects such as carbonization areas and partial dissolution in the gutta-percha and dentine were observed after laser applications $(12,16,25)$. Thus, 
the time of laser irradiation and energy power used should be considered when applying the laser in the root canal to avoid these thermal effects. However, none of the retreatment protocols or types of lasers were able to remove the remnants of filling materials completely from the root canal system $(8,25,33$, 34).

\section{CONCLUSION}

Different types of laser devices were evaluated for the removal of filling materials from root canal systems. Regardless of the disadvantages of lasers, including thermal effects, cracks, and carbonization, the laser devices were superior in removing and cleaning the root canal system in retreatment cases when compared with other devices. The time of laser irradiation and the output power should be considered to avoid the thermal effects of lasers. Because none of the retreatment techniques and devices were able to remove the filling materials completely from the root canal, further studies are required to evaluate the removal of root fillings by laser devices in combination with other materials and tools.

Peer-review: Externally peer-reviewed.

Author contributions: Concept - A.M., G.A.B.; Design - A.M.; Supervision - A.M.; Resource - G.A.B.; Materials - A.M., G.A.B.; Data Collection and/ or Processing - A.M., G.A.B.; Analysis and/or Interpretation - G.A.B.; Literature Search - A.M., G.A.B.; Writing - A.M.; Critical Reviews - G.A.B.

Conflict of Interest: Authors have no conflicts of interest to declare.

Financial Disclosure: The authors declared that this study has received no financial support.

\section{REFERENCES}

I. Marques da Silva B, Baratto-Filho F, Leonardi DP, Henrique Borges A, Volpato L, Branco Barletta F. Effectiveness of ProTaper, D-RaCe, and Mtwo retreatment files with and without supplementary instruments in the removal of root canal filling material. Int Endod $J$ 2012; 45(I0): 927-32. [Crossref]

2. Rödig T, Hausdörfer T, Konietschke F, Dullin C, Hahn W, Hulsmann M. Efficacy of D-RaCe and ProTaper Universal Retreatment NiTi instruments and hand files in removing gutta-percha from curved root canals-a micro-computed tomography study. Int Endod J 2012; 45(6): 580-9. [Crossref]

3. Rödig T, Kupis J, Konietschke F, Dullin C, Drebenstedt S, Hulsmann M. Comparison of hand and rotary instrumentation for removing gutta-percha from previously treated curved root canals: a microcomputed tomography study. Int Endod J 2014; 47(2): 173-82. [Crossref]

4. Martinho FC, Freitas LF, Nascimento GG, Fernandes AM, Leite FR, Gomes $A P$, et al. Endodontic retreatment: clinical comparison of reciprocating systems versus rotary system in disinfecting root canals. Clin Oral Investig 2015; 19(6): 1411-7. [Crossref]

5. Weichman JA, Johnson FM. Laser use in endodontics. A preliminary investigation. Oral Surg Oral Med Oral Pathol 197l; 3I(3): 4l620. [Crossref]

6. Christo JE, Zilm PS, Sullivan T, Cathro PR. Efficacy of low concentrations of sodium hypochlorite and low-powered Er,Cr:YSGG laser activated irrigation against an Enterococcus faecalis biofilm. Int Endod J 2016; 49(3): 279-86. [Crossref]

7. Shahriari S, Kasraei S, Roshanaei G, Karkeabadi H, Davanloo H. Efficacy of Sodium Hypochlorite Activated with Laser in Intracanal Smear Layer Removal: An SEM Study. J Lasers Med Sci 2017; 8(I): 36-4l. [Crossref]

8. Keleș A, Arslan H, Kamalak A, Akcay M, Sousa-Neto MD, Versiani MA. Removal of filling materials from oval-shaped canals using la- ser irradiation: a micro-computed tomographic study. J Endod 2015; 4I(2): 219-24. [Crossref]

9. Kamalak A, Uzun I, Arslan H, Keleș A, Doğanay E, Keskin C, et al. Fracture Resistance of Endodontically Retreated Roots After Retreatment Using Self-Adjusting File, Passive Ultrasonic Irrigation, Photon-Induced Photoacoustic Streaming, or Laser. Photomed Laser Surg 2016; 34(I0): 467-72. [Crossref]

10. Bader C, Krejci I. Indications and limitations of Er:YAG laser applications in dentistry. Am J Dent 2006; 19(3): 178-86.

II. Olivi G, DiVito EE. Advanced Laser-Activated Irrigation: PIPSTM Technique and Clinical Protocols. In: Olivi G, De Moor R, DiVito E, eds. Lasers in Endodontics. Cham: Springer; 2016: 216-91. [Crossref]

12. Tachinami $\mathrm{H}$, Katsuumi I. Removal of root canal filling materials using Er:YAG laser irradiation. Dent Mater J 20I0; 29(3): 246-52. [Crossref]

13. Gorduysus MO, Al-Rubai H, Salman B, Al Saady D, Al-Dagistani H, Muftuoglu S. Using erbium-doped yttrium aluminum garnet laser irradiation in different energy output levels versus ultrasonic in removal of root canal filling materials in endodontic retreatment. Eur J Dent 2017; II(3): 28I-6. [Crossref]

14. Kaptan F, Karapinar-Kazandag M, Kayahan MB, Bora T, Bayirli G. Potential of an Er:YAG Laser in the Removal of Calcium Hydroxide from Root Canals. Photomed Laser Surg 2012; 30(5): 250-4. [Crossref]

15. Jiang S, Zou T, Li D, Chang JW, Huang $X$, Zhang C. Effectiveness of sonic, ultrasonic, and photon-induced photoacoustic streaming activation of $\mathrm{NaOCl}$ on filling material removal following retreatment in oval canal anatomy. Photomed Laser Surg 2016; 34(I): 3-I0. [Crossref]

16. Suk M, Bago I, Katić M, Šnjarić D, Munitić MŠ, Anić I. The efficacy of photon-initiated photoacoustic streaming in the removal of calcium silicate-based filling remnants from the root canal after rotary retreatment. Lasers Med Sci 2017; 32(9): 2055-62. [Crossref]

17. Dönmez Özkan H, Kaval ME, Özkan G, Yiğit Özer S. Efficacy of Two Different Nickel-Titanium Rotary Systems in Retreatment Procedure with or Without Laser-Activated Irrigation: An In Vitro Study. Photobiomodul Photomed Laser Surg 2019; 37(8): 495-9. [Crossref]

18. Arslan H, Akcay M, Capar ID, Ertas H, Ok E, Uysal B. Efficacy of Needle Irrigation, EndoActivator, and Photon-initiated Photoacoustic Streaming Technique on Removal of Double and Triple Antibiotic Pastes. J Endod 2014; 40(9): 1439-42. [Crossref]

19. Li D, Jiang S, Yin X, Chang JW, Ke J, Zhang C. Efficacy of needle, ultrasonic, and EndoActivator irrigation and photon-induced photoacoustic streaming in removing calcium hydroxide from the main canal and isthmus: an in vitro micro-computed tomography and scanning electron microscopy study. Photomed Laser Surg 2015; 33(6): 330-7. [Crossref]

20. Arslan H, Akcay M, Capar ID, Saygili G, Gok T, Ertas H. An in vitro comparison of irrigation using photon-initiated photoacoustic streaming, ultrasonic, sonic and needle techniques in removing calcium hydroxide. Int Endod J 2015; 48(3): 246-5I. [Crossref]

21. Laky M, Volmer M, Arslan M, Agis H, Moritz A, Cvikl B. Efficacy and Safety of Photon Induced Photoacoustic Streaming for Removal of Calcium Hydroxide in Endodontic Treatment. Biomed Res Int 2018; 2018: 2845705. [Crossref]

22. Lin S, Liv Q, Peng Q, Lin M, Zhan Z, Zhang X. The ablation threshold of Er: YAG laser and Er, Cr: YSGG laser in dental dentin. Sci Res Essays 20I0; 5(I6): 2128-35.

23. Kuștarcı A, Er K, Siso SH, Aydın H, Harorlı H, Arslan D, et al. Efficacy of Laser-Activated Irrigants in Calcium Hydroxide Removal from the Artificial Grooves in Root Canals: An Ex Vivo Study. Photomed Laser Surg 2016; 34(5): 205-10. [Crossref]

24. Eymirli A, Nagas E, Uyanik MO, Cehreli ZC. Effect of Laser-Activated Irrigation with Ethylene Diaminetetraacetic Acid and Phytic Acid on the Removal of Calcium Hydroxide and Triple Antibiotic Paste from Root Dentin. Photomed Laser Surg 2017; 35(I): 43-8. [Crossref] 
25. Abdulialil M, Kalender A. Efficacy of Er,Cr:YSGG Laser with Different Output Powers on Removing Smear Layer After Retreatment of Two Different Obturation Techniques. Photobiomodul Photomed Laser Surg 2020; 38(2): 84-90. [Crossref]

26. Anjo T, Ebihara A, Takeda A, Takashina M, Sunakawa M, Suda H. Removal of two types of root canal filling material using pulsed Nd:YAG laser irradiation. Photomed Laser Surg 2004; 22(6): 470-6. [Crossref]

27. Yu DG, Kimura Y, Tomita Y, Nakamura Y, Watanabe H, Matsumoto K. Study on removal effects of filling materials and broken files from root canals using pulsed Nd:YAG laser. J Clin Laser Med Surg 2000; I8(I): 23-8. [Crossref]

28. Viducic D, Jukic S, Karlovic Z, Bozic Z, Miletic I, Anic I. Removal of gutta-percha from root canals using an Nd: YAG laser. Int Endod J 2003; 36(I0): 670-3. [Crossref]

29. Majori M, Bedini R, Filippini P, Altamura C, Caiazza S. SEM evaluation of canal walls after Nd:YAG laser removal of gutta percha. J Oral Laser Appl 2004; 4(4): 249-55.
30. Samiei M, Ghasemi N, Torab A, Rahimi S, Niknami M, Rikhtegaran $\mathrm{S}$, et al. Comparative CBCT evaluation of the efficacy of Nd:YAG laser and $\mathrm{K} 3$ rotary system in non-surgical root canal retreatment. Minerva Stomatol 2016; 65(I): II-6.

31. Farge P, Nahas P, Bonin P. In vitro study of a Nd:YAP laser in endodontic retreatment. J Endod 1998; 24(5): 359-63. [Crossref]

32. Keles A, Kamalak A, Keskin C, Akçay M, Uzun I. The efficacy of laser, ultrasound and self-adjustable file in removing smear layer debris from oval root canals following retreatment: a scanning electron microscopy study. Aust Endod J 2016; 42(3): I04-II. [Crossref]

33. Hulsmann $M$, Bluhm $\vee$. Efficacy, cleaning ability and safety of different rotary NiTi instruments in root canal retreatment. Int Endod $J$ 2004; 37(7): 468-76. [Crossref]

34. Bernardes RA, Duarte MA, Vivian RR, Alcalde MP, Vas- concelos $\mathrm{BC}$, Bramante CM. Comparison of three retreatment techniques with ultrasonic activation in flattened canals using micro-computed tomography and scanning electron microscopy. Int Endod J 2016; 49(9): 890-7. [Crossref] 